\title{
Study on Developing Chinese College EFL Learners' Pragmatic Competence in Relation to Language Proficiency and Overseas Experience
}

\author{
Zhen $\mathrm{Hu}$ \\ Shanghai Second Polytechnic University, Shanghai, China
}

\begin{abstract}
Pragmatic competence refers to both knowledge of the linguistic forms which realize particular illocution, and knowledge of the appropriate use of the linguistic forms in certain social contexts. It is an important part of the language proficiency construct. However, studies in China show that College English students' pragmatic competence is poor. Unlike second language learners, students learning English as a foreign language in China do not have many opportunities to be exposed to authentic language use. If they are not provided with sufficient pragmatic knowledge, they will have more difficulty in understanding and producing appropriate use in the target language. This paper focuses on the development of pragmatic competence and awareness on the part of college English learners in China. Overseas experience and language proficiency are treated as two main variables which may influence students' PC development. With some data collection from students in Shanghai Second Polytechnic University, findings shows that there are significant differences in the acquisition of pragmatic competence between students with overseas experience and students without overseas experience, yet no significant differences in the acquisition of pragmatic competence between students with high and low language proficiency.
\end{abstract}

Index Terms—pragmatic competence, developing, Chinese college students

\section{RESEARCH BACKGROUND}

There is no doubt that English is becoming an international language for trade and education in the global context (Pakier, 1999). The role of English, especially communicative competence in English, which refers to both the knowledge of language and the ability to use that knowledge in social interactions (Barron, 2003; Hymes, 1972; Widdowson, 1992) has become more and more important in the daily life of people in China. Therefore, it is important to investigate how EFL learners in China acquire their language knowledge in common learning contexts, which will help them improve their language competence much. Chinese College students, as a major group of EFL learner in China, should be particularly examined around both their communicative competence and the sub-theme of pragmatic competence in the current research. Pragmatic competence is the ability of a second language learner or a foreign language learner to use the target language appropriately in corresponding social contexts (Taguchi, 2009).

\section{A. Chinese College English Syllabus and Curriculum}

College English is an integrative university course. It is a two-year compulsory subject for non-English major students at university level. College English teaching in China is guided by the curriculum document. The first version of College English Curriculum Requirements was implemented in 1985, which indicated that the objective of college English teaching was to develop learners' language skills, such as reading, listening, speaking and writing, and laid great emphasis on linguistic competence. It also required students in key universities to pass the College English Test (CET-4) before graduation. The second version of College English Curriculum Requirements was published in 1999. It aimed to further strengthen learners' linguistic competence. Developing learners' communicative competence was also mentioned, but there was no explicit explanation on what communicative competence was and how to develop it. All university students were required to pass College English Test (Band Four) before graduation. Under the guidance of these two requirements, College English teaching was teacher-centered, examination-oriented with emphasis on developing linguistic competence. Since that late 1990s, the notion that language teaching should not only include grammar, semantics, but also pragmatics, has been introduced to the College English teachers in China. This inclusion is further emphasized with the release of a new College English Curriculum Requirements in 2007. It emphasizes "language use, social interactions, and cultural quality". English teaching and learning in China should no longer be confined to the acquisition of grammatical knowledge. The development of communicative competence should also become a primary goal of the teaching of English as foreign language. College English teacher need to focus on the development of communicative competence, among which pragmatic competence is one of the main components.

\section{B. Chinese Current College English Learning}


With continuous education innovation and the fast development of Chinese economy, college English students are facing great challenges. They are required to learn pragmatic and cultural knowledge as well as linguistic knowledge in order to become competent in cross-cultural communication. According to Requirement 2007, the focus of College English learning has changed from reading to listening and speaking. What's more, special attention is given to independent learning by means of multimedia tools. This movement suggests a shift from the long established grammar-translation and teacher-centred language practices towards learning for communication and communicative competence (Lamie, 2001).

However, some studies in China show that College English students' pragmatic competence is poor (Liu, 2004; Men \& Liu, 2000; Zhang, 2002). Like the non-English majors in my university, students can do well in a test but fail to use English effectively when they engage in spontaneous conversations. Students complain that after years of language study, they still cannot order breakfast in English. The general concerns of language practitioners and students all point to a less than desirable sentiment, which culminates in a disgruntled dismissal of the current language teaching as producing "mute" or "deaf" language learners with poor pragmatic competence.

Unlike second language learners, students learning English as a foreign language in China do not have many opportunities to be exposed to authentic language use. If they are not provided with sufficient pragmatic knowledge, they will have more difficulty in understanding and producing appropriate use in the target language. Being a main source of input in the learning environment, classroom input play an important role in English language teaching, particularly in the English as a foreign language classroom (Kim \& Hall, 2002; Bardovi-Harlig, 2001) as they are the essential elements in determining learners' pragmatic competence( Bardovi-Harlig, 2001). Therefore, it is necessary to strengthen the importance of pragmatics in College English learning and teaching processes.

\section{LITERATURE REVIEW ON PC STUDIES}

Before constructing the theoretical framework, it is necessary to review the empirical studies concerning development in L2 pragmatic competence worldwide.

One of the first longitudinal developmental studies on L2 pragmatic competence was conducted by Schmidt (1983). In this study, Schmidt collected data on the acquisition of English by a Japanese adult living in Hawaii. He mainly analyzed an obvious transfer of Japanese sociopragmatic and pragmalinguistic norm. Later, Schmidt and Frota (1986) kept on doing this research and provided certain evidence of the development in conversational ability.

Bardovi-Harlig and Hartford (1993) focused on 16 adult L2 students' developing ability of producing suggestions and rejections in the environment of academic advising sessions. It was found that students' sociopragmatic ability seemed to develop faster than their pragmalinguistic ability.

Siegal $(1994,1996)$ conducted a longitudinal study to examine the speech production of three English learners and one Hungarian learners of Japanese as L2. It found that the learner subjectivity and proficiency had great influence on the development of learners' pragmatic competence.

Barron's (2003) study also made a contribution to the research on the pragmatic development. She examined how 33 Irish learners of German developed their ability of speech act realization in a studying abroad context.

Besides the longitudinal studies, a number of cross-sectional studies are also concerned with. Scarcella (1997) examined politeness strategies applied respectively by 10 beginners and 10 advanced learners of ESL. It showed that the participants' ability of choosing politeness forms outweighed that of using the forms appropriately.

The Cross-cultural Speech Act Realization Project (Blum-kulda \& Olshtain, 1984) investigated the speech act of requests and apologies in eight language varieties. With those data, Blum-Kulka's (1989) study showed one of the frequently used request strategies was conventional indiretness.

Fukushima's (1990) study was aimed at the request performance of Japanese EFL learners. Results showed that the participants' request was direct regardless of different social contexts.

Garcia (2004) investigated the pragmatic awareness of low and high proficiency ESL learners. It was found that the target speech act could be successfully identified by the ESL learners to different extents.

The above reviewed studies can be summarized as follows: first, most of them managed to record the development of L2 pragmatic competence by working on the development of either production or comprehension of particular speech acts (Request, apology, greeting, etc.). Second, most of the subjects investigated were with L1 backgrounds other than Chinese. Third, the data were collected by means of learning diaries, Discourse Completion Task, oral production task, etc. It is evident that there are very few empirical studies investigating the development of L2 pragmatic competence in China.

\section{RESEARCH METHODS}

\section{A. Participants}

A total of 40 non-English major students from Shanghai Second Polytechnic University participated in the current study. Among them twenty-two are males and eighteen are females, age ranging from 19 to 22 . Twenty of them are from regular English classes and another twenty are from advanced English classes (Regular and advanced classes are divided by their English language proficiency when they entered university, advanced classes enrolled the students who 
ranked the first $25 \%$ in enrolment English proficiency tests). Ten students from the advanced classes attended the overseas study and internship project held by SSPU (study or internship abroad for 90 days), who spent 90 days in Queensland University of Technology and lived as home stay, so they encountered genuine communicative situations in Australia. In the group of regular class students, nine of them got overseas experience. 4 of them spent around 30 days in English speaking countries in order to attend summer camp there; 3 of them spent more than 30 days there for family business and they had a big chance to communicate with English native speakers; And another 2 students just travelled around English-speaking countries around 20 days, and as interpreters because they were all not led by any travel guide. In the researcher's perspective, those low-language-proficiency students all got similar overseas experience to practice their English in genuine English contexts, though they did not receive any formal education there.

Besides, before administering the questionnaire to the students, the researcher encouraged the participants to attend IELTS in order to confirm their language proficiency. Consequently, 19 of them achieved 6 and 6 above, 3 of them achieved 5.5-6, and 18 of them achieved 5.5 and below 5.5. According to their objective language proficiency, the participants have been classified as shown in table 1 .

TABLE 1

CLASSIFICATION OF PARTICIPANTS

\begin{tabular}{|l|l|l|l|}
\hline Group & Number of students & Descriptions & Abbreviation for group \\
\hline 1 & 10 & $\begin{array}{l}\text { Low English language proficiency without } \\
\text { overseas experience }\end{array}$ & L-O \\
\hline 2 & 8 & $\begin{array}{l}\text { Low English language proficiency with } \\
\text { overseas experience }\end{array}$ & L+O \\
\hline 3 & 13 & $\begin{array}{l}\text { High English language proficiency without } \\
\text { overseas experience }\end{array}$ & H-O \\
\hline 4 & 9 & $\begin{array}{l}\text { High English Language proficiency with } \\
\text { overseas experience }\end{array}$ & H+O \\
\hline
\end{tabular}

\section{B. Instruments for Data Collection}

The data of this study are collected via questionnaire consisting of 2 parts. The first part contains a series of demographic questions about students' gender, linguistic proficiency, year of learning English, overseas experiences and self-comment on English learning. The second part includes nine communicative situations which students are likely to meet in real life contexts. These items are selected on the basis of an extensive review of literature on pragmatic competence. Those open-ended questions aim to draw out the students' personal responses. Students were free to answer these questions by providing any information of their language learning experiences that was relevant. The total nine situations included 3 about declining an offer or refusing, 3 about responding to a compliment, and 3 about giving apologies, which are all displayed in the Speech Act Theory to show the level of pragmatic competence. Since the researcher came to the UK, those items have already been examined by random-selected native English speakers. They approved that the questionnaire was appropriate and provided their normal answers for further references.

When evaluating the acceptability of the responses given by the students in relation to nine different situations, the researcher not only collaborated with a native speaker expert but also had a control group of native English speaking correspondents. They are English teachers working in park hill primary school and university of Birmingham. By the great help of them, the researcher can determine whether the given responses by the students are acceptable $(\sqrt{ })$ or unacceptable $(\times)$.

\section{Data Collection Procedures}

The instrument required 30 minutes to complete and administered in those students regular English classes. Before students started, they were informed that their responses to the questionnaires would remain confidential and their answers should be written as clearly as possible, which is crucially important to the success of this research.

\section{Data Analysis Procedures}

The data obtained via the questionnaire were coded descriptive analysis, which is utilized to obtain patterns demographic information from the personal details part of the questionnaire and pragmatic competence. The Statistical Package for the Social Science (SPSS 16.0) was employed for statistical analysis. A series of independent samples were employed to explore whether there were significant differences in the learning of pragmatic competence by linguistic proficiency and overseas experience.

\section{E. Hypothesis}

This study was performed to explore how language proficiency and overseas experience are related to the acquisition of pragmatic competence. It set out the hypotheses:

a. There are significant differences in the acquisition of pragmatic competence among Chinese college EFL students of non-English majors in relation to linguistic proficiency.

b. There are significant differences in the acquisition of pragmatic competence among Chinese college EFL students of non-English majors in relation to overseas experience. 


\section{FINDINGS}

\section{A. The Overall Pragmatic Competence Analysis of Chinese College ELT Students}

In the questionnaire, all the students show a high level of grammatical competence in English language. 29 students $(72.5 \%)$ did not make any grammatical mistakes when providing all the answers. While only $12(30 \%)$ students exhibited a high level of pragmatic competence by giving acceptable answers to all the items. Comparing to NS participants' answers, students are lack of competence to show their ideas in an appropriate way.

In situation 1, a friend invites you to go to the cinema on weekend. Yet you have to do some revision for the exam. Then you will say_. The frequency of the individual components of the speech as set for this prompt can be found in table 2 .

\begin{tabular}{|l|l|}
\hline \multicolumn{2}{|c}{ TABLE 2} \\
\hline Components & Frequency of Use \\
\hline Expression of regret & $55 \%$ \\
\hline Excuse & $85 \%$ \\
\hline Offering alternative & $12 \%$ \\
\hline
\end{tabular}

The findings showed that most subjects avoided refusing directly by employing an indirect refusal. More than a half students expressed their regret of not being able to accept the invitation, and most of them provided excuses or reasons as a way to convey their inability or unwillingness. However, there a small amount of students who tried to give an alternative for their absence at the party. It was found that college students had realized that they need to show politeness in social interactions. It is impolite in china to give a direct refusal "no" to decline an invitation. When a small group of students used direct refusal, they provided additional excuses as well. These findings confirmed that non-native speakers produced few offers of alternative excuses (Tanck, 2004) but did not neglect the social interaction of politeness.

In situation 2, your American boss asks you to work overtime today. Yet you do not want to do any extra work. Then you will say_. The frequency of the individual components of the speech as set for this prompt can be found in table 3:

\begin{tabular}{|l|l|}
\hline Components & Trequency of Use \\
\hline Expression of regret & $85 \%$ \\
\hline Direct refusal & $10 \%$ \\
\hline Excuse & $96 \%$ \\
\hline
\end{tabular}

Students tended to respond to this prompt using a polite refusal, perhaps considering the relationship between an employee and a boss. However, almost every student provided excuses for their not being able to work overtime.

The data indicated that students responded appropriately for the relationship in this prompt, and tried to indicate the correct kind of politeness in the interaction. These data complied with the notion of sociopragmaitcs, in that language learners needed to obtain proper knowledge of relevant social and cultural values that could help them vary their speech strategies in communication (Harlow, 1990; Kasper, 1997). Yet, in low-language-proficiency group, 2 students had a very low level of pragmatic competence for this particular situation. Not understanding cultural and social elements and lacking social strategies in using English may lead to pragmatic failures in social interactions.

In situation 3, your friend asks you to lend him some money, and promises to return it to you in two weeks. You do not want to lend him. Then, you will say_. The frequency of the individual components of the speech as set for this prompt can be found in the following table 4 :

\begin{tabular}{|l|l|}
\hline Components & TABequency of Use \\
\hline Expression of regret & $97 \%$ \\
\hline Direct refusal & $20 \%$ \\
\hline Excuse & $90 \%$ \\
\hline
\end{tabular}

Friends keep an equal and close relationship with each other. The data indicate that almost all the students show their regrets and gave excuses in making refusals. Most of them avoided using direct refusals. Speakers need to consider face-saving strategies to protect the requester's face when refusing the request. Only 1 student in group H-O directly responses "no way, guy, you need to earn by yourself". The requester would feel awkward in such a context.

The findings in relation to giving refusals highlighted that Chinese college students had learned what speech acts of refusals were, but not all of the participants understood how to correctly apply them appropriately to all situations. The improper use of refusal speech acts led to pragmatic failures in communication.

In situation 4, a friend compliments you on your new hair style. Then you will say_. The frequency of sequence categories used to make responses to the compliment can be found in table 5: 
TABLE 5

\begin{tabular}{|l|l|}
\hline Category type & Frequency of Use \\
\hline Accept & $88 \%$ \\
\hline Reject & $9 \%$ \\
\hline Deflect/evade & $4 \%$ \\
\hline
\end{tabular}

The data indicated that most students accepted the compliment and show their acceptance of compliment by saying "thank you". Students applied an appreciation token, agreeing utterance, and return compliment to show their politeness and pleasure to accept the compliment. 1 student in group L-O rejected the compliment by employing a disagreeing utterance. Students employed phrases and norms that were often used in Chinese to achieve the same purpose in applying the target language. (Schauer, 2009). 10 students gave deflective responses by providing the information comment. Such responses are acceptable in the Chinese context as it is a common way for Chinese people to respond in their mother tongue. People try to show their modesty when offering compliment responses. It is considered as one of the core values of Chinese culture that guides Chinese communication behaviour ( $\mathrm{Wu}, 2011)$ which is a further indication that language learners' first culture affects the use of their target language (Liaw, 2006).

In situation 5, a friend compliments you on the presentation you gave in speech contest. The frequency of sequence categories used to make responses to the compliment can be found in table 6 :

TABLE 6

\begin{tabular}{|l|l|}
\hline Category type & Frequency of Use \\
\hline Accept & $71 \%$ \\
\hline Reject & $19 \%$ \\
\hline Deflect/evade & $8 \%$ \\
\hline
\end{tabular}

Students tried to appear humble and used excuses to downgrade their efforts in order to show their modesty. Chinese people are taught to keep lower when they receive a compliments or praises. This does not mean that the Chinese do not think positively of themselves but the norm of Chinese society is to be modest (Chen, 1993)

In situation 6, you are a newly appointed sales manager. One of your employees praised you much when having lunch with a group of colleges. The frequency of sequence categories used to make responses to the compliment can be found in table 7:

TABLE 7

\begin{tabular}{|l|l|}
\multicolumn{2}{c}{ TABLE 7} \\
\hline Category type & Frequency of Use \\
\hline Accept & $60 \%$ \\
\hline Reject & $22 \%$ \\
\hline Deflect/evade & $15 \%$ \\
\hline
\end{tabular}

The speaker has a "top-down" relationship with the interlocutor in this situation. The identity of a manager has to be considered in giving the appropriate response when responding to compliments. The data indicate that most of the students used appropriate acceptance strategies, amendment strategies and combined strategies in providing compliment responses.

The findings highlighted that college English students were familiar with situations of giving compliment responses. They could provide the basic appreciation tokens to accept compliments, and they were able to consider the speaker's identity and the relationship when giving responses. Some were able to select appropriate strategies to give compliment responses $(\mathrm{Yu}, 2003)$. However, a number of students directly translate their response from Chinese to English without considering the context and the appropriateness of their responses. They were not able to recognize errors and repair pragmatic failures that may cause the breakdown of communication.

In situation 7, you are late for group study because you sleep in. Then, you will say components of the speech act for this prompt can be found in table 8:

\begin{tabular}{|l|l|}
\multicolumn{2}{c}{ TABLE 8 } \\
\hline Components & Frequency of Use \\
\hline Regret & $98 \%$ \\
\hline Responsibility & $70 \%$ \\
\hline Remedy & $28 \%$ \\
\hline
\end{tabular}

The data indicated that almost every student apologized for the lateness. Responsibilities were explained. Less than $30 \%$ of the students express their willingness to make up for the offense. In this situation, the speaker and recipient held an equal relationship. Students provided similar reasons that might be often used as excuses for lateness in the Chinese context. 1 student in group $\mathrm{L}+\mathrm{O}$ could not convey intentions effectively.

In situation 8 , you broke the vase borrowed from your friend, you will say to him. Then you will say_. The frequency of use of the components of the speech act for this prompt can be found in table 9 : 


\begin{tabular}{|l|l|}
\begin{tabular}{|l|l|}
\hline \multicolumn{2}{c}{ TABLE 9} \\
\hline Remponents & Frequency of Use \\
\hline Responsibility & $50 \%$ \\
\hline Remedy & $31 \%$ \\
\hline
\end{tabular}
\end{tabular}

The data indicated that most of apologies offered by the students contained an apology and regret for the offense. More than half students the apologies stated the speaker's responsibility for the offense, and more than $30 \%$ of the apologies provide a remedy and promise for committing the offense. It demonstrated that many college students were able to recognize the apology situation and apply proper expressions of apology. Many provided an apology together with an indication of taking responsibility as well a promise to rectify the situation in order to win forgiveness from the recipient.

In situation 9, as an English teacher, you have realized the mistake that you failed one student because of wrong calculation of score. Then you will say to the student this prompt can be found in table 10: . The frequency of use of the components of the speech act for

\begin{tabular}{|l|l|}
\multicolumn{2}{c}{ TABLE 10} \\
\hline Components & Frequency of Use \\
\hline Regret & $95 \%$ \\
\hline Responsibility & $68 \%$ \\
\hline Remedy & $80 \%$ \\
\hline
\end{tabular}

As discussed above, speakers' different identities influence the choice of discourses. As a teacher, it is necessary to show politeness always. Almost all the students were aware of the identity and employed suitable words and speech acts to express their regret. Remedies provided by the students showed their willingness to make up for the mistake. This kind of appropriate social behaviour in such a social interaction helps to avoid pragmatic failure in communication (Rose\& Kasper, 2001).

Findings from the questionnaire (DCTs) indicated that on the whole Chinese college EFL learners were not high level language practitioners in pragmatic competence. Although they could recognize different situations, they were still lack of ability to apply their language knowledge to the real situations effectively. Most of them merely provided simple responses without extended well-organized information, which might be a block in intercultural communication.

\section{B. The Acquisition of Pragmatic Competence by Linguistic Proficiency}

In order to measure whether there were significant differences in the acquisition of pragmatic competence among those four group students, a paired sample T-test was employed to compare the groups. According to participants' overseas experience, the four groups had been organized into two pairs. The first pair included students with overseas experience, and another pair included students without overseas experience. In each pair, high language level and low language level students displayed no significant differences, which was opposed to the previous hypothesis. There were no significant differences in the acquisition of pragmatic competence between $\mathrm{H}+\mathrm{O}$ and $\mathrm{L}+\mathrm{O}$, or $\mathrm{H}-\mathrm{O}$ and $\mathrm{L}-\mathrm{O}$ by their language proficiency (p>.05, See table 11).

TABLE 11

PAIRED SAMPLES TEST

\begin{tabular}{|c|c|c|c|c|c|c|c|c|}
\hline & \multicolumn{5}{|c|}{ Paired Differences } & \multirow[b]{3}{*}{$\mathrm{t}$} & \multirow[b]{3}{*}{ df } & \multirow[b]{3}{*}{ Sig. (2-tailed) } \\
\hline & \multirow[b]{2}{*}{ Mean } & \multirow[b]{2}{*}{ Std. Deviation } & \multirow[b]{2}{*}{ Std. Error Mean } & \multicolumn{2}{|c|}{$95 \%$ Confidence Interval of the Difference } & & & \\
\hline & & & & Lower & Upper & & & \\
\hline Pair $1 \mathrm{H}+\mathrm{O}-\mathrm{L}+\mathrm{O}$ & .375 & 1.685 & .596 & -1.034 & 1.784 & .629 & 7 & .549 \\
\hline Pair 2 H-O - L-O & -.100 & 1.969 & .623 & -1.509 & 1.309 & -.161 & 9 & .876 \\
\hline
\end{tabular}

\section{The Acquisition of Pragmatic Competence by Overseas Experience}

To analyze whether there were significant differences in the acquisition of pragmatic competence among four group students, a paired sample t-test was conducted to compare the means of the four groups. In high language proficiency and low language proficiency groups, significant differences could be displayed here. As predicted, there were significant differences in the acquisition of pragmatic competence between students with overseas experience and students without overseas experience ( $\mathrm{p}<.05$, table 12), no matter they are high language proficiency or low language proficiency students 
TABLE 12

PAIRED SAMPLES TEST

\begin{tabular}{|c|c|c|c|c|c|c|c|c|}
\hline & \multicolumn{5}{|c|}{ Paired Differences } & \multirow[b]{3}{*}{$\mathrm{t}$} & \multirow[b]{3}{*}{ df } & \multirow[b]{3}{*}{ Sig. (2-tailed) } \\
\hline & \multirow[b]{2}{*}{ Mean } & \multirow[b]{2}{*}{ Std. Deviation } & \multirow[b]{2}{*}{ Std. Error Mean } & \multicolumn{2}{|c|}{$95 \%$ Confidence Interval of the Difference } & & & \\
\hline & & & & Lower & Upper & & & \\
\hline Pair $1 \mathrm{H}+\mathrm{O}-\mathrm{H}-\mathrm{O}$ & 2.444 & 1.740 & .580 & 1.107 & 3.782 & 4.214 & 8 & .003 \\
\hline Pair 2 L+O - L-O & 1.625 & .744 & .263 & 1.003 & 2.247 & 6.177 & 7 & .000 \\
\hline
\end{tabular}

\section{CONCLUSIONS}

Findings from the current study indicated that students with higher linguistic proficiency gave more acceptable responses to the communicative situations than those students with lower linguistic proficiency. This result was in coordinate with previous studies conducted by Carrel (1984), Takahashi and Beebe (1987).

Similarly, overseas experience has helped the participants of the current study to develop their pragmatic competence. Those students with overseas experience had a high level of pragmatic perception, which supported the idea that second language learning contexts proved richer input than foreign language learning contexts for learners' exhibiting convergence to native speaker pragmatic behaviour (Jular, 2007)

Since intercultural communication tasks are more related with participants' intercultural social relationships and entail intercultural communicative acts, the language teacher should try to give those tasks in foreign language classroom. Students need to be engaged in various social roles and speech events by means of incorporation of activities, such as role play, simulation, and drama into the classroom. Cultural elements are necessary to be involved in college English learning, and cultural comparison activities are quite helpful.

To sum up, PC should be treated as a prominent ingredient of language development as phonological, morphological syntax and semantic improvement. Promoting pragmatic competence is crucial to cultivate a powerful communicator in the target language. Youngsters in China need an opportunity to become such communicator in the future international competition. The current study indicated that teaching pragmatics must be included in the EFL context in Chinese college English teaching, furthermore, the overseas study and internship projects should be necessarily widespread in colleges, which will much trigger the development of Chinese college students' pragmatic competence.

\section{REFERENCES}

[1] Bachman, Lyle. F. (1990). Fundamental Considerations in Language Testing. New York: Oxford University Press.

[2] Bardovi-Harlig, Kathleen. (2001). Empirical evidence of the need for instruction in pragmatics. In K.R.Rose \& G. Kasper (Eds.), Pragmatics in language teaching. New York: Cambridge University Press, 13-32.

[3] Bardovi-Harlig, Kathleen., \& Hartford Beverly. (1993). Learning the rules of academic talk: A longitudinal study of pragmatic change. Studies in Second Language Acquisition, 15, 279-304.

[4] Barron, Anne. (2003). Acquisition in interlanguage pragmatics: learning how to do things with words in a study abroad context. Amsterdam/Philadelphia: John Benjamins Publishing Company.

[5] Blum-Kulka, House, \& Kasper. (Eds.). (1989). Cross-Cultural Pragmatics: Requests and Apologies. Norwood, J. J.: Ablex.

[6] Boxer, Diana. (2002). Discourse issues in cross cultural pragmatics. Annual review of applied linguistics, 22, 150-167.

[7] Carrell, Patricia. L. (1984). Inferencing in ESL: Presuppositions and implications of active and implicative predicates. Language Learning, 34, 1-21.

[8] Chen, Rong. (1993). Responding to compliments: A contrastive study of politeness strategies between American English and Chinese speakers. Journal of pragmatics, 20(1), 49-75.

[9] Fukushima Saeko. (1990). Offers and requests: Performance by Japanese learners of English. World Englishes, 9, 317-325.

[10] Garcia, Paula. (2004). Developmental Differences in Speech Act Recognition: A pragmatic awareness study. Language Awareness, 13, 96-115

[11] Harlow, Linda L. (1990). Do they mean what they say? Sociopragmatic competence and second language learners. The Modern Language Journal, 74, 328-51.

[12] Hymes, Dell. (1972). On communicative competence. In J.B Pride \& J. Holmes (Eds.), Sociolinguistics, Harmondsworth: Penguin, 269-285.

[13] Jular, Elena. Maria. (2007). The Development of intercultural awareness and changes of beliefs: The effects of studying abroad on learners of English as a second language. http://www.recercat.net/bitstream/2072/8977/1/ElenaMerino.pdf (accessed 02/01/2013).

[14] Kasper, Gabriele. (1997). Can pragmatic competence be taught? Second language teaching and curriculum centre, University of Hawai'i. Retrieved from http://nflrc.hawaii.edu/NetWorks/Nw06 (accessed 28/11/2012).

[15] Kasper Gabriele. \& Blum-Kulka, Shoshana (1993). Interlanguage Pragmatics. Oxford: Oxford University Press.

[16] Kasper, Gabriele. \& Rover, Carsten. (2005). Pragmatic in second language learning. In E. Hinkel (Ed.), Handbook of Research in Second Language Teaching and Learning, Mahwah, New Jersey: Lawrence Erlbaum Associates, Inc., 317-334.

[17] Kim, Daejin., \& Hall, Joan.Kelly. (2002). The role of an interactive book reading program in the development of second language pragmatic competence. The Modern Language Journal, 86(iii), 332-348.

[18] Lamie, Judith M. (2001). Understanding change: The impact of in-service training on teachers of English in Japan. Huntington, NY: Nova Science Publishers. 
[19] Leech, Geoffrey. (1983). Principles of Pragmatics. London: Longman.

[20] Liaw, Mee-ling. (2006). E-learning and the development of intercultural competence. Lauguage Learning and Technology, 10(3), 49-64.

[21] Meng, Mei. \& Liu, Qinliang. (2000). A research report on university students' pragmatic competence. Journal of Xi'an Foreign Language Unversity, 8(4), 92-94.

[22] Pakier, Anne. (1999). Connecting with English in the context of internationalization. TESOL Quarterly, 33 (1), $103-114$.

[23] Savignon, Sandra. (1991). Communicative language teaching. Theory into Practice. Reading, MA:Addison-Wesley.

[24] Schauer, Gila. A. (2009). Interlanguage pragmatics development: The Study Abroad context. London: Continuum.

[25] Schmidt, Richard. (1983). Interaction, acculturation, and the acquisition of communicative competence: A case study of on adult. In Wolfson, N., Judd, E. Sociolinguistics and language acquisition. Rowley, MA: Newbury House, 137-174.

[26] Siegal, Meryl. (1996). The role of learner subjectivity in second language sociolinguistic competency: Western women learning Japanese. Applied Linguistics, 17, 356-382.

[27] Taguchi, Naoko. (Ed.) (2009). Pragmatic Competence. Berlin: Mouton De Gruyter.

[28] Takahashi, tomoko. \& Beebe, Leslie M. (1987). The development of pragmatic competence by Japanese learners of English. JALT Journal, 8, 131-155.

[29] Tanck, Sharyl. (2004). Speech Act sets of refusal and complaint: A comparison of native and non-native English speakers' production. TESOL Working Papers, 4(2), 1-22.

[30] Thomas, Jenny. (1983). Cross-cultural pragmatic failure. Applied Linguistics, 4(2), 91-112.

[31] Trosborg, A. (1995). Interlanguage pragmatics: request, complaints and apologies. Berlin, New York: Mouton De Gruyter.

[32] Wu, Ruey-Jiuan. Regina. (2011). A conversation analysis of self-praising in everyday Mandarin interaction. Journal of Pragmatics, 43(13), 3152-3176.

[33] Zhang, Xiaomei. (2002). College English teaching and development of pragmatic competence. Journal of South China University of Technology (Social Science Edition), 4(1), 73-78.

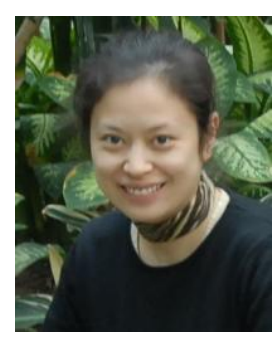

Zhen Hu, born on June $16^{\text {th }} 1979$, in Henan province, China, achieved her M.A in Shanghai Maritime University with major in Applied Linguistics in year 2004. Now she is a professional English teacher in the Faculty of Foreign languages of Shanghai Second Polytechnic University. In 2013, she was promoted as associated professor in SSPU.

From January to November of 2013, she is doing her personal research as an academic visitor in University of Birmingham, UK. Some publications are listed below: Drama Translation: A pragmatic perspective (Salt Lake City, US: academic press corporation, 2010); Improving intercultural Pragmatic Competence by appreciating original English films (article of Movie literature, China, 2011). Her research interests focus on the field of application of pragmatics, such as pragmatic translation, pragmatic approaches in EFL learning. 